\title{
The Effect of COVID-19 CORONA VIRUS on Sustainable Teaching and Learning in Architecture Engineering
}

\author{
Dr.Hind Abdelmoneim Khogali ${ }^{1}$ \\ ${ }^{1}$ College of Architecture Engineering and Digital Design, Dar Al Uloom University, Saudi Arabia, Riyadh City. \\ Correspondence: Dr.Hind Abdelmoneim Khogali, College of Architecture Engineering and Digital Design, Dar \\ Al Uloom University, Saudi Arabia, Riyadh City.
}

Received: June 2, 2020

doi:10.5539/mas.v14n8p44
Accepted: July 10, 2020

Online Published: July 14, 2020

\begin{abstract}
On 11 March, the World Health Organization (WHO) announced that the COVID-19 outbreak became a global pandemic. The governments have been implementing measures to limit the number of people congregating in public places. Therefore, the Ministry of Education stated that all educational institutes should complete the 2019-2020-2 semester using online video conferences and virtual classes. The aim of this research is to study the effect of COVID-19 on teaching and learning during the last three months of lockdown after shifting to virtual classes. The research study the procedures applied by the College of Architecture Engineering in Dar Al Uloom University. The Adding value is improving the E-Learning process for the upcoming semesters and solving the negative points for a better education. To achieve this objective the researcher, distribute a survey to the students to scale their experience and record the positive points, and to find a solution to the negative points to solve these problems. The outcome of the research showed a good experience and many recommendations to be applied in the coming future.
\end{abstract}

Keywords: teaching and learning on architecture engineering colleges, develop the learning outcome, the effect of COVID-19 on teaching and learning

\section{Introduction}

On 11 March, the World Health Organization (WHO) announced that the COVID-19 outbreak became a global pandemic. Congruent with the directives of the Ministry of Education and stemming from Dar Al Uloom University continued commitment to quality education, and to bringing the academic term to a successful conclusion, different procedures have been applied. On 15 March, the university sent an official email to all faculty members to complete the semester using the Microsoft team in the virtual classes, the Learning Management System (LMS), and the university email to communicate to the students. The following procedures have been implanted by the college of Architecture Engineering in Dar Al Uloom University:

\subsection{Develop the Courses Syllabus}

a) Total Grade distribution: $80 \%$ for the pre-final continuous assessment, and $20 \%$ for the final exam.

b) The midterm exam and the final be conducted online through the LMS.

c) All the assignments should be uploaded in the LMS.

d) The design studio projects should be discussed virtual in the Microsoft team program.

e) The teacher can use the whiteboard for further explanation to the students (see table 1).

\subsection{Develop the Course Learning Outcomes}

The college of Architecture Engineering started comprehensive workshops for the faculty members on developing the program and course learning outcomes. The focus of the research will be on the History of Architecture, Landscape, Sanitary, and Technical and Environmental Control courses. 
Table 1. Show the development of course assignments with the course learning outcome

Course Learning Outcomes in Domains of Learning and Alignment with Assessment Methods and Teaching

\begin{tabular}{|c|c|c|c|c|c|c|c|c|}
\hline \multicolumn{9}{|c|}{ Strategy } \\
\hline Code & Learning Domains & Assig\# & Assig\# & Assig\# & Assig\# & Assig\# & Mid & Final \\
\hline \# & And Course Learning Outcomes & 1 & 2 & 3 & 4 & 5 & Term & Exam \\
\hline 1.0 & \multicolumn{8}{|c|}{ Knowledge } \\
\hline & $\begin{array}{l}\text { Outline technical and aesthetical } \\
\text { solutions for site/landscape projects }\end{array}$ & & & & & & 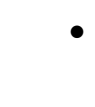 & • \\
\hline 1.1 .1 & $\begin{array}{l}\text { through comprehensive integration of } \\
\text { different technical operations. }\end{array}$ & & & & & & & \\
\hline
\end{tabular}

Identify design problems providing their solutions with sensitivity to

2.0.1 technical, esthetical, social and built environment aspects, through analysis, criticism, and potential resolutions. Interpersonal Skills \& Responsibility

Illustrate the ability of problem-solving

3.0.1 and critical thinking in both individual and group discussions.

Communication, Information Technology, Numerical

Communicating the project and the design process through IT relevant specific graphic design programs (Photoshop, AutoCAD, 3D Studio).

\section{Cognitive Skills}

Produce an overall comprehension of

building facilities details, plumbing

details, or building components for a particular architectural design.

\subsection{Develop the Course Content}

i. Landscape and urban design course

a) All courses achieved the knowledge in midterm, exams, and final exams.

b) Cognitive skills are achieved by five weekly assignments, analyzing case studies in the local and international landscape and gardens, and analyzing the design studio site.

c) Interpersonal skills are achieved by uploading all the assignments in LMS.

d) Communication skills are achieved by encouraging the students to discuss their assignments through the virtual classes during the lectures. The discussion is directed by the teacher and sometimes between the students in groups.

e) The Psychomotor skills in the design and draw are achieved through the AutoCAD program (the semester small project of the landscape).

f) The teaching method is done by using the PowerPoint presentation. 
g) Continuous evaluation is given to the student in LMS and during the lecture. Feedbacks from the students is obtained at the end of the lecture.

I. History of Architecture course

a) The knowledge is achieved in the midterm, short exam, and final exam.

b) Cognitive skills are achieved by five weekly assignments, analyzing case studies in the history of middle ages and pre-historic architecture, and compare between different eras.

c) Interpersonal skills are achieved by uploading all the assignments in LMS and attending the virtual class on time.

d) Communication skills achieved by encouraging the students to discuss their assignments through the virtual classes during the lectures. The discussion is directed to the teacher and sometimes between the students in groups.

e) The Psychomotor skills in drawing sketches are achieved at home. The sketch is submitted in LMS.

f) The teaching method is done by using the PowerPoint presentation.

g) Continuous evaluation is given to the student in LMS and during the lecture.

II. Sanitary and technical course

a) The knowledge is achieved in the midterm, short exam, and final exam.

b) Cognitive skills are achieved by five weekly assignments, design and draw through the AutoCAD program (the semester design projects), and apply the sanitary and technical on them.

c) Interpersonal skills are achieved by uploading all the assignments in LMS, attending the virtual class on time.

d) Communication skills are achieved by encouraging the students to discuss their assignments through the virtual classes during the lectures. The discussion is directed to the teacher and sometimes between the students in groups.

e) The Psychomotor skills in the design and drawing are achieved through the AutoCAD program at home. The sketch is submitted in LMS.

f) The teaching method is done by using the PowerPoint presentation.

g) Continuous evaluation is given to the student in LMS and during the lecture. The Rubric is used and given to the students.

III. Environmental control

a) All courses achieved the knowledge in midterm, short exams, and final exams.

b) Cognitive skills are achieved by five weekly assignments, analyzing case studies in local and international levels, analyse Riyadh climate, and draw a sketch of the courtyard system and wind tower.

c) Interpersonal skills are achieved by uploading all the assignments in LMS and student research group work.

d) Communication skills is achieved by encouraging the students to discuss their assignments through the virtual classes during the lectures. The discussion is directed by the teacher and sometimes between the students in groups.

e) The Psychomotor skills are achieved through drawing a sketch of wind tower and courtyard system

f) The teaching method is done by using the PowerPoint presentation.

g) Continuous evaluation is given to the student in LMS and during the lecture.

1.4 Develop the Student Learning and Management System (LMS)

The Quality Unit provided a comprehensive workshop to DAU Staff explaining the eight standards of E-Learning and stated that faculty members should develop his/her LMS page, everything should be clear for the student, we should upload the course syllabus, course specification, lectures, online exams, and student manual.

\subsection{The Objective of the Paper and the Add It Value}

The main objective of the paper is to study Dar Al Uloom University experience during the three months in the E-Learning and the virtual classes. The Adding value is improving the E-Learning process for the coming 
semester and future, and solving the negative points for a better education. To achieve this objective the researcher used a survey to scale the students' response to this experience and record the positive points and the negative points, and suggest a solution to solve these problems. We must improve our experience especially after the announcement WHO that COVID-19 became an outbreak.

\section{Research Method}

The research is quantitative research based on a survey distributed to the students in architecture college. The survey tool is used to record their response towards teaching and learning in the virtual classes. It is made using the Google Forms and sent to 54 students after they completed their final exams during the time between 10/May/2020 and 20/May/2020. The survey contains 15 questions, including 5 categories, general information, the response of the student about design studios and theocratical courses, the technical problems facing the students during the virtual class, health problems, the response of students towards the method of assessment.

A qualitative interview was done in virtual classes to record the response of the students especially in the problems facing them. Most of the students facing health problems in their eyes and back because of ling classes about 6 students they do not have laptops.

A Comparison between Dar Al Uloom University experience and Yarmouk University experience in Jordan was done in virtual meeting (Webinar S. R., 2020), they said that they have the same experience in the E-Learning and virtual classes, they added two points: the first point is that the total number of the students in the class should not exceed 20 students. The second point is the students in the first year in Architecture school need more time and effort to learn them the basic engineering drawing, they solve this problem by giving them easy exercises during the COVID-19 time and concentrated in isometric drawings.

\section{Literature Review}

\subsection{Medical Support}

(Solution, 15-5-2020) stated that COVID-19 affected employees' wellbeing and business continuity. It affected the building system, interior design space, housekeeping, nourishment and fitness, architectural design, plumbing and bathroom design, innovative technologies, political, and standards. Therefore, post-COVID-19 workplace strategies were made in order for the employee to be safe. The solutions can be in using HVAC systems and air circulations, social distancing in the interior design places, using smart solutions in the public spaces and in the bathrooms. (WHO, 2020) announced that COVID-19 became a global pandemic and this has affected our social life, health, and education.

The Saudi Center of Disease Pretension and Control, (Control, 2020), published a report on how we can control the COVID-19 spread. They said that institutions should follow the standard precautions, which include:

- Mask should be available.

- Regular check the soap and the Sanitizing bottle in its places. The hand Sanitizing should be near the door and in the main halls and in the bathrooms that everyone can found it and use. Signs and orientations for COVID-19 should be posted near it.

- Avoid direct contact with blood, body fluids, secretions (including respiratory secretions). Standard precautions also include prevention of needle-stick or sharps injury;

- Safe waste management; cleaning and disinfection of equipment, and cleaning of the environment.

- Using eye protection (facemask or goggles), because sprays of secretions may occur.

- $\quad$ Limit infected person movement within the institution and ensure that they wear a medical mask when moving around.

- $\quad$ Ensure that there are healthcare workers to perform aerosol-generating procedures for emergency cases (i.e. open visit suctioning of the respiratory tract, high-flow nasal oxygen, non-invasive ventilation, intubation, bronchoscopy, cardiopulmonary resuscitation. In addition, the Saudi Center of Disease Pretension and Control published a report to show the general steps that should be done by peoples.

The social distancing as a method of reducing the spread of Covid-19 have resulted in productivity losses, disruption in business, and may cause a cost impact in the long term, according to (MEED, 2020). The key is how that record is maintained and how it is going to be produced to substantiate the claim. The social distancing has affected some courses in architecture college that require a site as a part of learning procedures and learning outcome. These courses are building construction, design studio, construction document, landscape and urban, and urban design. 


\subsection{Training and Lectures Support}

UNESCO's said that COVID-19 tells us the scientific cooperation is the key when dealing with a global public health issue. It tells us that continued education must be ensured when so many children today cannot go to school. It is a stark reminder of the importance of quality, reliable information, at a time when rumors are flourishing. It tells about the power of culture \& knowledge to strengthen human fabric and solidarity, at a time when so many people around the world must keep social distance and stay at home. UNESCO is fully committed to supporting governments for distance learning, open science, knowledge, and culture sharing as a fundamental means to stand together and tighten the bonds of our shared humanity, (UNESCO, 2020). Following the UNESCO orientation due to the extraordinary circumstances that the world is witnessing after the COVID-19 outbreak, it became crucial to continue the education online and make it happen. According to (SRF_Webinar, 2020), they said the institution should develop the skills of E-Learning for the faculty members by doing workshops and training program and continuous education for faculty members and built the learning environment. The University of Dar Al Uloom provided three workshops during 30/July/2020 about the E-Learning Standards Applying the Quality Matters Rubric (APPQMR, 2020)", the workshops explained the eight standards of the E-Learning to improve the online teaching and learning process for the next semester. During the workshop they recommended two websites to visit: (1) Universal Design for Learning (UDL, 2020). They set a guidelines and framework for learning to provide multicable means of learning in engagement, responsibilities, action and experience. (2) Web Content Accessibility Guidelines (WCAG, 2020). It covers a wide range of recommendations for making web content more accessible for a wide range of people.

Robert, J Howlett published a book in 2019 named "Smart Education and the E-Learning", (Robert, 2019). In chapter four he talks about the students' virtual collaborative engagement, while in chapter eight he talked about developing students' research skills, using of LMS system to communicate with the students.

Sonia Patel wrote an article about "the Top 6 eLearning Trends Of 2019", (Patel, 2019). She stated that eLearning is getting bigger and better. It seems there is no stop-we are being creative and innovative like never before she said that the top 6 e-learning trends are: microlearning, artificial intelligence, gamification, adaptive learning, video, and mobile learning. These trends have excelled themselves this year, making eLearning much more learner-centric and more interactive in the virtual classes.

It is important for the students in the virtual class to be engaged in the lecture and the discussion. Dr. Muhammed Alhasan Abdullah said in his webinar on YouTube, June 8, (SRF-Webinars, 2020), in order to achieve this, engagement should be self-directed, task-oriented, goal oriented, and should be between the teacher and the student or between the students themselves in groups. Additionally, Dr. Maysara Issa Mohiuddin said in his webinar on YouTube, May 29, (SRF-Webinar, 2020), the effective learning should be student centred, two-way discussion, continuous evaluation and feedback, per- reflection, interaction engagement, and this could be achieved by different teaching methods such as groups discussion, pair discussion, groups presentation, sharing conference lectures between male and females in the conference room.

It is important to receive feedbacks from the students about the online classes to take the positive and manage the negative points. A research published in WILEY library entitled "Audio peer Feedback to Promote deep Learning in Online Education investigated the relationship between providing and receiving audio peer feedback with a deep approach to learning within online education" stated that students may be supported by online audio peer feedback as a method to choose a deep approach to learning, (Renée M. Filius1, 17 March 2019).

\subsection{Technical Support}

The college of Business in Dar Al Uloom University, (Buisness, 2020), announced the following rules for electronic exams;

- The exam will be conducted at home because of COVID-19.

- The teacher should manage the online exam on the Student Learning Manage System (LMS).

- The exam should have a student password.

- The student should be in the Microsoft team room during the exam duration and other regulations according to the university's online exam rules. The Information Technology Support (Support, 2020) published a booklet to orient the teachers about the online exams followed by a workshop for the faculty member on Microsoft Teems Program.

- Every student should have a laptop, operation system windows vista 10, Google Chrome, Microsoft teams on desktop. 
- The online exam should be a one-way exam the student should answer the questions and go forward, it is not allowed the student to go back.

- The questions have limited time to be answered to avoid any plagiarism.

- The IT should provide student manual for the students and for the teachers in How they can use the LMS, everything should be clear to the student and to the teacher in How they can upload their assignments, How they can make their online exams, How they can see their continuous at the end of the semester

- The teacher should upload all the materials in the LMS including the PowerPoint presentation, videos, e-books, supporting Links from the internet, announcements, photos and tables.

\subsection{Research Support}

Ms. Alia Ahmed in the National College of Business Administration \& Economics in Pakistan stated that their experience on the online classes was excellent, and they did not miss even one class, (Alia AhmedAltaf-ur Rehman, 2020). They distributed 4 surveys to measure the experience, kept on working as a team, and eventually things started shaping up and settling down. The report concluded that staff maintaining their high and lively spirit as usual, for being so brave and optimistic in the face of this virus-ridden situation. However, a view of the data also points out that a hybrid teaching solution of in-class and online teaching will need to be deployed and going forward. A hybrid solution mandates an LMS, customized to our institution. As mentioned earlier COVID-19 may just prove to be the turning point towards a "digital world". (Admiraal, May 2020) stated that we should use technologies in teaching and learning, and focus on learning not teaching concentrate on active learning.

\section{Research Results}

At the end of the semester, a survey was distributed to the students in five courses; Landscaping, History of pre-Historic Architecture, History of Middle Ages, Sanitary and Environmental control. The result of the survey is shown in Figure 5 to Figure 16.
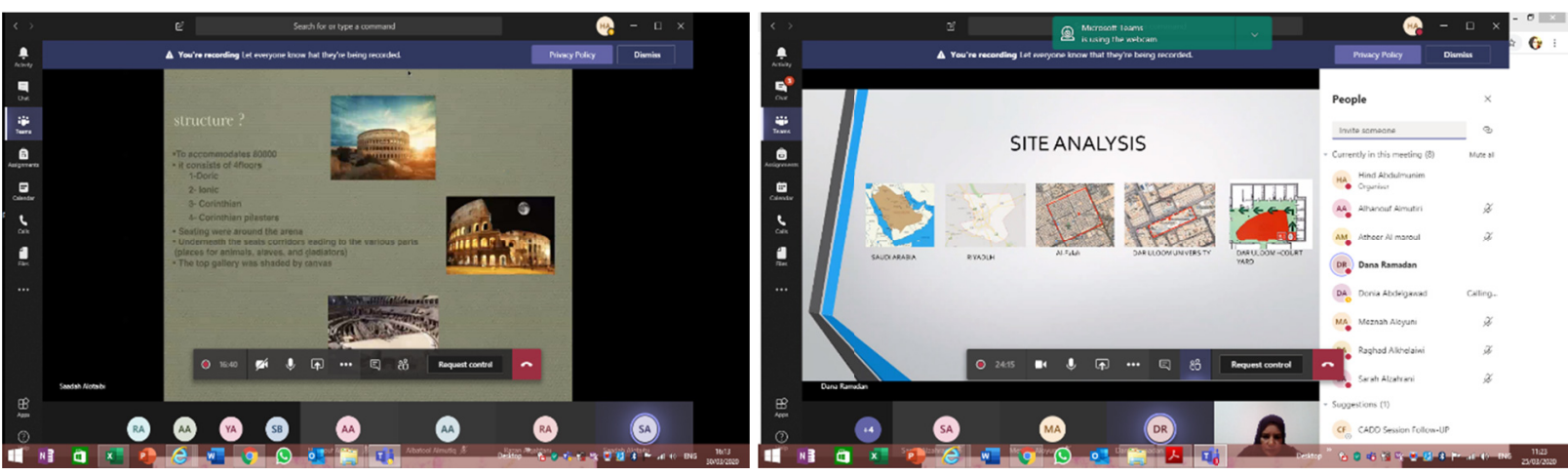

Figure 1. Online Lecture on History of Architecture

Figure 2. Online lecture on Environmental Control
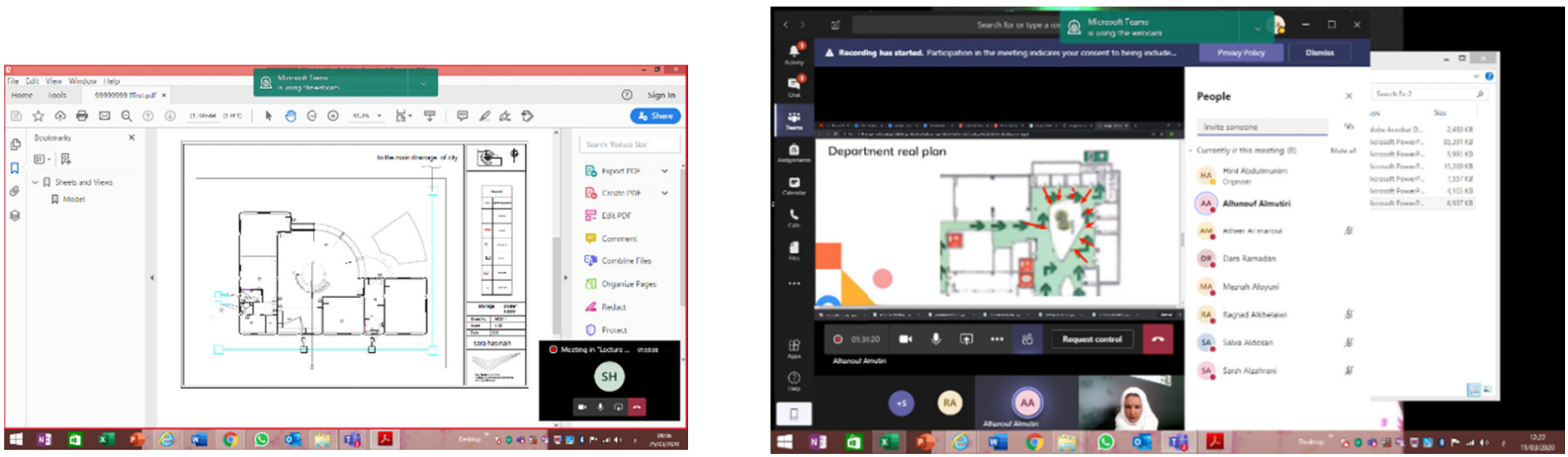

Figure 3. Online lecture on Sanitary and Technical

Figure 4. Online lecture on Landscape and urban design. 


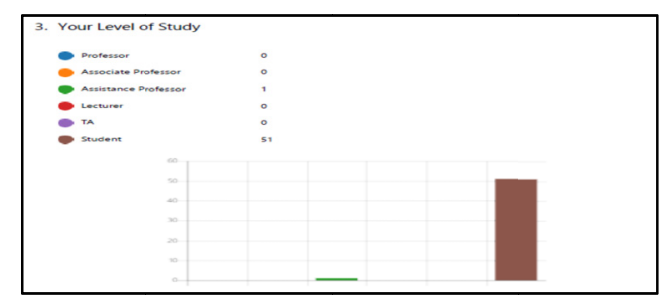

Figure 5. Shows the level of study

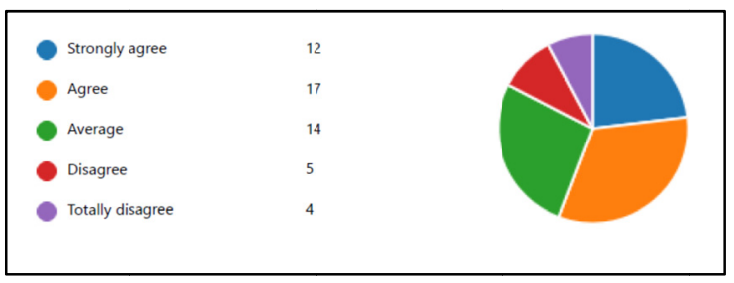

Figure 7. Do you think your experience with the online learning was effective?

\begin{tabular}{|l|l|}
\hline word program & 12 \\
Excel program & 2 \\
Auto Cad & 36 \\
3D Max & 2 \\
\hline
\end{tabular}

Figure 9. Which program you used in the assignments?

\begin{tabular}{|ll|}
\hline Strongly Agree & 14 \\
Agree & 20 \\
Average & ${ }^{13}$ \\
Disagree & 2 \\
Strongly disagree & 3 \\
\hline
\end{tabular}

Figure 11. How you describe your experience with the theoretical courses like landscape, history of architecture, Environmental control, and Sanitary

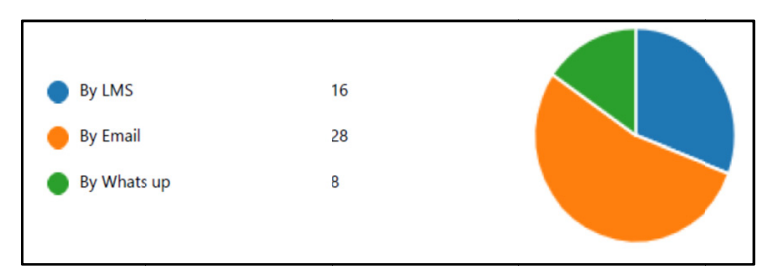

Figure 13. Which methods of interacting you used?

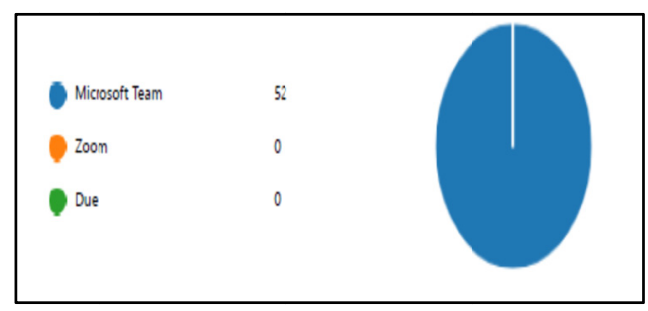

Figure 6. which program you used?

\begin{tabular}{|l|l|}
\hline power point & 28 \\
writing reports & 2 \\
projects & 9 \\
drawing sketches & 5 \\
Design projects & 9 \\
\hline
\end{tabular}

Figure 8 . Which type of exercise was more effective?

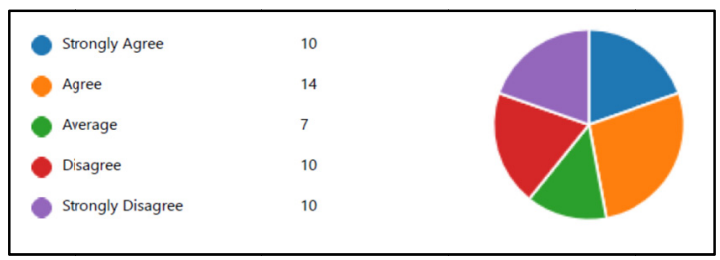

Figure 10. How do you describe your experience with the Design Studio in the online classes?

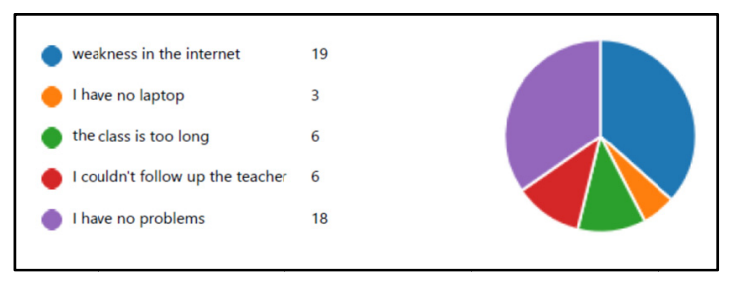

Figure 12. During the online class, did you face any technical problems?

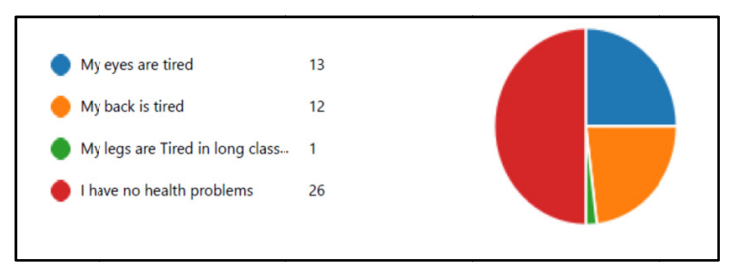

Figure 14. During the online class, did you face any health problem? 


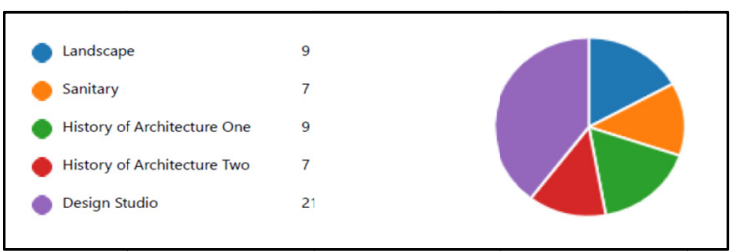

Figure 15. Which course was more exciting to you?

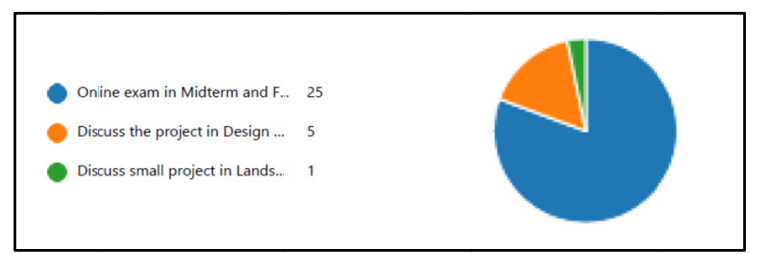

Figure 16. Which methods of assessment is more effective

Table 2. conclusion of the results

\begin{tabular}{|c|c|c|c|c|c|}
\hline & $\begin{array}{l}\text { Strongly } \\
\text { Disagree }\end{array}$ & Disagree & Average & Agree & Strongly Agr \\
\hline \multicolumn{6}{|l|}{$\begin{array}{c}\text { Which } \\
\text { Program you } \\
\text { use online }\end{array}$} \\
\hline Microsoft Team & & & & & $100 \%$ \\
\hline Zoom & $\mathbf{x}$ & & & & \\
\hline Due & $\mathbf{x}$ & & & & \\
\hline $\begin{array}{l}\text { Do you think } \\
\text { that your } \\
\text { experience with } \\
\text { online classes } \\
\text { are is effective }\end{array}$ & $8 \%$ & $10 \%$ & $27 \%$ & $33 \%$ & $23 \%$ \\
\hline \multicolumn{6}{|l|}{$\begin{array}{l}\text { Which type of } \\
\text { exercises are } \\
\text { more effective }\end{array}$} \\
\hline PowerPoint & & & & & $53 \%$ \\
\hline Small projects & & & $17 \%$ & $4 \%$ & \\
\hline \multicolumn{6}{|l|}{ Design projects } \\
\hline $\begin{array}{l}\text { Drawing } \\
\text { sketches }\end{array}$ & & $9 \%$ & & & \\
\hline Writing reports & $17 \%$ & & & & \\
\hline \multicolumn{6}{|l|}{$\begin{array}{l}\text { Which } \\
\text { program you } \\
\text { used in your } \\
\text { assignments }\end{array}$} \\
\hline Word program & & & & & $235 \%$ \\
\hline Excel program & & & & $4 \%$ & \\
\hline AutoCAD & & & $56 \%$ & & \\
\hline 3D Max & & $4 \%$ & & & \\
\hline $\begin{array}{c}\text { How you } \\
\text { Describe your } \\
\text { experience with } \\
\text { Design Studio } \\
\text { in online classes }\end{array}$ & $10 \%$ & $10 \%$ & $7 \%$ & $27 \%$ & $20 \%$ \\
\hline $\begin{array}{c}\text { How you } \\
\text { describe your } \\
\text { experience with } \\
\text { theoretical }\end{array}$ & $6 \%$ & $4 \%$ & $25 \%$ & $38 \%$ & $27 \%$ \\
\hline
\end{tabular}




\section{classes like \\ landscape, \\ history,}

Sanitary, etc.

During the

online class do

you facing any

problems like

Weakness in the

internet

Have no laptop

The class is too

$$
\text { long }
$$
$12 \%$

Couldn't follow up the teacher

I have no problems

Which method

of interacting

with your

teacher you use

By LMS

By Email

By What's up

During the online class did you face health problems in

My eyes are tired

My back is tired

$12 \%$

legs are Tired in long classes

I have no health problems

Which is the more exciting course for you

Landscape

Sanitary

History of

Architecture

One

History of

Architecture

Two

Design Studio

$21 \%$
$54 \%$

$15 \%$

$25 \%$

$23 \%$

$2 \%$

$50 \%$

Which method 


\section{of Assessment is more Effective?}

Online exam in

Midterm and

Final

Discuss the

projects during

Design Studio

Discuss the

projects in

Sanitary

Write your
opinion about
the whole
experience of
the online
classes

A bad
experience
- I actually
don't like it
- Bad idea for
architecture
class

-we have been

wronged with

the studio

because of

distance

education

- Design Studio

is not effective

for online

classes
$81 \%$

$16 \%$

$3 \%$

some are good
and some are
very bad
-It depends on
the quality of
the student's
devices and the strength
- I think it's a
good experience
when we study
classes like a
landscape

\author{
I loved the \\ experience of \\ my online \\ classes \\ - t was good not \\ as bad as I \\ expected. \\ despite that in \\ university it's \\ more efficient \\ with design \\ studio courses. \\ overall
}

- The teachers

helped make it

easy on us and

made sure we

all understood it

was a nice

experience

- Unique

experience

Table 2 shows the results show that most of the students have a good experience of the E-Learning and the virtual classes, in the theoretical and practical courses. Some students are facing problems such as eye problems, back problems because of the long classes time. About 6 students they don't have laptops and most of the student are facing internet problems, it's a general problem and extend few seconds. Most of the students like exams as a perfect way for the assessment method. In addition, most of the students used LMS, university email and wats-up to contact their teacher. $38 \%$ of the student they are disagree about their experience in design studio. Most of the students strongly agree to use PowerPoint presentation in their discussion and assignments.

\section{Discussion the Results}

All students are studying in the College of Architecture and Digital Design. All the students used the Microsoft Teams Program by the orientation of the university after the comprehensive workshop to the students and teachers by IT Unit. $23 \%$ of the students strongly agree that their experience with the online e-learning is quite good, $33 \%$ of the students agree, while $18 \%$ of the students disagree.

$53 \%$ of the students strongly agree to use PowerPoint in their assignments, $4 \%$ of the students prefer small projects

$17 \%$ of the students prefer design projects, $9 \%$ of the students disagree with the drawing sketches. In addition, $17 \%$ of the students strongly disagree with writing reports assignments. In program used, 23\% of the student's used word program, $4 \%$ of the students used Excel program, 54\% of AutoCAD program, $4 \%$ of the students used 3D Max program. In addition, in the practical courses $20 \%$ strongly agree with their experience with design studio virtual classes, $21 \%$ agree, $7 \%$ neutral, and $20 \%$ disagreeing with their experience in virtual design studio classes 
while, $27 \%$ of the students strongly agree with the theoretical course's virtual classes. In the problems facing by the online classes are: $27 \%$ reported having internet weakness problems, $6 \%$ of the students said they do not have Laptops, $12 \%$ of the students said that the virtual class is too long, $12 \%$ of the students could not follow up the teacher, while $37 \%$ of the students said they did not have any problems with the virtual classes. In addition, $25 \%$ of the students are facing eyes problems during the virtual classes, $23 \%$ are facing back problems, $2 \%$ are facing legs problems because of sitting long period of time, while $50 \%$ have no health problems. On the other hand, $31 \%$ of the students communicate with the teacher by LMS, and $51 \%$ of the students communicate by email, and $15 \%$ used WhatsApp.

$17 \%$ said that the Landscape course is the most excited course for them, while $13 \%$ of the students said that sanitary course is the most exciting course to them. On the other hand, $13 \%$ of the students disagree that history of Architecture is the most exciting course of them, and $27 \%$ of the students strongly disagree that design studio is the most exciting course for them. Also, $81 \%$ of the students strongly agree that online exams are the most effective method of assessment on the online e-learning. $16 \%$ of the students agree that the discussion during the design studio is the most effective method of assessment, while $3 \%$ of the students are neutral.

The last question is an open question to write student's opinion about the virtual classes. Most of the students said it was a good experience, other students said it was a bad experience to them. Table 3 shows the assignments applicable during the lockdown and the inapplicable assignments.

Table 3. Analysis's method of assessment before and during the COVID-19

\begin{tabular}{cccc}
\hline List of Method of Assessment & Before Covid-19 & During COVID-19 & Notes \\
\hline Quizzes & Applicable face to face in & Applicate in the online & The most efficient \\
& University campus & system using the Microsoft & method of evaluation \\
Midterm and Final Exams & Applicable face to face in & Applicate in the online & The most efficient \\
& University campus & system using the Microsoft & method of evaluation
\end{tabular}

Assignments:

Drawing Sketches

Compare between two case

studies, or between different

era

Analyzing a case study

PowerPoint seminar and presentation
Applicable face to face in

University campus

Applicable face to face in

University campus

\begin{abstract}
Applicable face to face in
University campus
\end{abstract}

Applicable face to face in

University campus
Applicate at home. The assignment is uploaded in the

LMS and discussed in the

online system using

Microsoft Team and LMS

Applicate at home. The

assignment is uploaded in

LMS and discussed in the

online system using

Microsoft Team and LMS

Applicate at home. The

assignment is uploaded in

LMS and discussed in the

online system using

Microsoft Team and LMS

Applicate at home. The

assignment is uploaded in the

LMS and discussed in the

online system using

Microsoft Team and LMS
The students agree with

the assignment

The students agree with the assignment

The students agree with the assignment

PowerPoint presentation was the most exciting exercise for the students 


\begin{tabular}{|c|c|c|c|}
\hline Discussing small projects & $\begin{array}{l}\text { Applicable face to face in } \\
\text { University campus }\end{array}$ & $\begin{array}{l}\text { Applicate at home. The } \\
\text { project is uploaded in LMS } \\
\text { and discussed in the online } \\
\text { system using Microsoft } \\
\text { Team and LMS }\end{array}$ & $\begin{array}{l}\text { Students were facing } \\
\text { difficulties in solving the } \\
\text { problems in the } \\
\text { designing. The teacher } \\
\text { used the whiteboard to } \\
\text { draw sketches for } \\
\text { students to understand the } \\
\text { problem }\end{array}$ \\
\hline $\begin{array}{l}\text { Discussing design studio } \\
\text { projects }\end{array}$ & $\begin{array}{c}\text { Applicable face to face in the } \\
\text { University campus }\end{array}$ & $\begin{array}{l}\text { Applicate at home. The } \\
\text { project is uploaded in LMS } \\
\text { and discussed in the online } \\
\text { system using Microsoft } \\
\text { Team and LMS }\end{array}$ & $\begin{array}{l}\text { Students facing } \\
\text { difficulties in solving the } \\
\text { problems in designing. } \\
\text { The teacher used the } \\
\text { whiteboard to draw } \\
\text { sketches for students to } \\
\text { understand the problem }\end{array}$ \\
\hline The Collaborative skill & $\begin{array}{c}\text { Applicable between } \\
\text { Architecture program and } \\
\text { Interior program. }\end{array}$ & $\begin{array}{c}\text { Not applicable between the } \\
\text { two programs because of } \\
\text { Lock }\end{array}$ & $\begin{array}{l}\text { Collaborative skills can } \\
\text { be applied in groups in } \\
\text { the same virtual class. }\end{array}$ \\
\hline Site visit & Applicable & Not applicable & $\begin{array}{l}\text { During COVID-19 the } \\
\text { students used Google } \\
\text { Map to study the site }\end{array}$ \\
\hline 3D Model & Applicable & Not Applicable & $\begin{array}{l}\text { The students are not able } \\
\text { to use the 3D Model Lab, } \\
\text { so we used 3D-Max } \\
\text { instead and made a video }\end{array}$ \\
\hline
\end{tabular}

Table 4. Sample of Learning outcome achieved during COVID-19, course History of Architecture, from course report showing the assessment results of the course during COVID-19 which is Excellent and very good

$\begin{array}{cc}\text { NQF Learning Domains } & \text { List methods of } \\ \text { and Learning Outcomes } & \text { assessment } \\ \text { for each LO }\end{array}$

1.0

1.1 Recognize the state of ancient architecture in the different eras: Prehistoric, Egyptian, Mesopotamian Romans, Greek, Byzantine, ancient Japanese, and ancient Indian until reaching Early Christian Architecture

1.2 Memorize the impact of social and political influences on ancient architecture features such as materials, construction systems, and ornaments openings..., etc

\section{Knowledge:}

Multiple and continuous assessment methods: assignments and bonus, mid-term $(80 \%)$.

Summative assessment methods: final exam $(20 \%)$

Multiple and continuous assessment methods: assignments and bonus, mid-term $(80 \%)$.

Summative assessment methods: final exam $(20 \%)$
Summary analysis of assessment results

for each $\mathrm{LO}$

\section{$90 \%$ \\ ILO Achieved}

$80 \%$

ILO Achieved 
2.1 Compare between architectures from different time and region (Egyptian Architecture and

Mesopotamian Architecture or Romans Architecture and Greek Architecture)

\subsection{Analyze case study from the prehistoric architecture in Egyptian, Mesopotamian, Greek, and Romans Architecture}

\subsection{Interpersonal Skills \& Responsibility:}

3.1 Demonstrate a proper vocabulary individually and in group work

\subsection{Communication, Information Technology, Numerical: \\ 4.1 Presenting research by using IT programs: Photoshop, AutoCAD, Powerpoint}

\section{0} 5.1

\section{Psychomotor:}

Hand drawing sketches of buildings in ancient architecture
Multiple and continuous assessment methods:

assignments and bonus, mid-term $(80 \%)$.

Summative assessment methods: final exam (20\%)

Multiple and continuous assessment methods: assignments and bonus, mid-term $(80 \%)$.

Summative assessment methods: final exam

$(20 \%)$

Multiple and continuous assessment methods: assignments and bonus, mid-term $(80 \%)$.

Summative assessment methods: final exam

$(20 \%)$

Multiple and continuous assessment methods: assignments and bonus, mid-term $(80 \%)$.

Summative assessment methods: final exam $(20 \%)$

Multiple and continuous assessment methods: assignments and bonus, mid-term $(80 \%)$.

Summative assessment methods: final exam $(20 \%)$
ILO Achieved

$89 \%$

ILO Achieved

$85 \%$

ILO Achieved

$100 \%$

ILO Achieved

$71 \%$

ILO Achieved

\section{Conclusion}

The research concluded that workshops and continuous training programs are becoming crucial during COVID-19. Additionally, developing the program learning outcomes and the course syllabus, course report and course specification and course contents should be a continuous process to suit the situation of the lock of COVID-19. The assessment method should be supported by the continuous evaluation of the students by quizzes, assignments, the midterm exam should be from $80 \%$ and the final exam from $20 \%$ congruent with the directives of the Ministry of Education. The research concluded that the university and the college should include the E-Learning system as a part of the education process, and it should be activated when need it. In addition, the student-manual should be included health orientation during COVID-19 time. The teacher should encourage the students to communicate through the LMS, emails, and other messaging apps such as WhatsApp to solve any problem facing the students. A survey was sent to the students asking them about the problems they are facing the virtual. Our results show that most of the students are facing weakness on the internet. It is recommended to raise these problems to the IT to solve the weakness on the internet. Others said that the class is too long, and 
they cannot follow-up with the teacher. This problem can be solved by making the duration of the class not more than two hours for the lecture and the discussion. A minority of the students $(6 \%)$ reported that they do not have a laptop. These students could be helped by a social loan from the university for a long period of time. The research recommends that the questions of the exams should be short, easy, and depends on the student's knowledge.

Finally, the teachers should post the course syllabus and course specifications on LMS. In addition, they should post all their lectures, videos, eBooks, useful links, announcements assignments orientations, and the online exams. The IT should provide a student manual explaining to the students how to use the LMS to upload their assignments, communicate with their teacher, and follow up the announcement. limitations in current research and future researches should be added in this area the effect of COVID-19 on teaching and learning and records the lessons learned.

\section{Acknowledgement}

The Researcher would like to acknowledge Dar Al Uloom University, especially the Deanship of Graduate studies and research for funding this research.

\section{References}

APPQMR. (2020, June 30 Tuesday). Applying the Quality Matters Rubrics. Retrieved from PPQMR: https://www.qualitymatters.org/professional-development/workshops/higher-ed-appqmr

Alia AhmedAltaf-ur Rehman, A. I. (2020). REPORT ON ONLINE TEACHING AND LEARNING AMID COVID-19. Bakistan: National College of Business Administration \& Economics (NCBA\&E), Lahore (Pakistan), https://doi.org/10.13140/RG.2.2.25997.36320/1.

Admiraal, W. (May 2020). Teaching and learning from home - what we have learned from pre-COVID-19 times. Engineering students' perception of workplace English in Turkey (p. 100). Turkey: Leiden University Graduate School of Teaching, https://www.researchgate.net/publication/341266777_Teaching_and_learning_from_home_-_what_we_hav e_learned_from_pre-COVID-19_times.

Buisness, C. o. (2020). Electronic Exams Gudelines for students. Saudi Arabia: Dar Al Uloom University.

Control, S. C. (2020). Health Practitioner Infection Control Measures. Saudi Arabia: Saudi Center of Desease Prevension and Control.

Control-2, S. C. (2020). Booklet orientation Against COVID-19 in workplace. Saudi Center of Desease Prevension and Control.

MEED. (2020). COVID-19 Sparks Contract Issues. UK: MEED Business.

Patel, S. (2019). Top 6 eLearning Trends Of 2019. French: E-Learning Industry, https://elearningindustry.com/.

Renée M. Filius1, R. A. (17 March 2019). AudioPpeer Feedback to Promote deep Learning in Online Education. Journal of Comuter Assessment Learning, WILEY, https://doi.org/10.1111/jcal.12363

Robert, J. H. (2019). Smart Education and e-Learning. USA: Springer.

Solution, E. D. (15-5-2020). Post COVID-19 Work place Stratigies. Vasant Vihar, New Delhi: Environmental Design Solution Pvt Ltd.

SRF_Webinar. (2020, June 2 Tuseday). Medical Health Professional Education Wibinars durring COVID-19 and After. Retrieved from You Tube Chanel: https://www.youtube.com/watch?v=3WoPkryZDo0

SRF-Webinar. (2020, May 29, Friday). My Experience with Effective and Innovative Engineering Learning. Retrieved from Youtube: https://www.youtube.com/watch?v=uWzmdU2KGiA\&fbclid=IwAR0zoQSuJukSIRqbtM_HelDPQN5exqiX oKA0GcKNTrPDaigOVsoW_UDYO0A

SRF-Webinars. (2020, June 8, Monday). E- Engagement of the E-Learning during COVID-19. Retrieved from You Tube: https://www.youtube.com/watch?v=eHtjKfeaAwI

Support, I. T. (2020). LMS Exam Setting. Saudi Arabia: Dar Al Uloom University.

UNESCO. (2020, June 21 Sunday). COVID-19 Resonse. Retrieved from UNESCO: https://en.unesco.org/covid19

UDL. (2020, July 5 Sunday). Universal Design for Learning UDL. Retrieved from UDL: 
http://udlguidelines.cast.org/

Webinar, S. (2020, May 11 Thursday). Changing in The E-Learning in Sudan Between the Present and The Future. Retrieved from Youtube channel: https://www.youtube.com/watch?v=U8MB8Mg5NyU

Webinar, S. R. (2020, June 20 Sat.). The Effect of COVID-19 in Teaching and Learning in Architecture Engineering Colleges. Retrieved from YouTube: https://www.youtube.com/watch?v=ehp0Ufis-QI\&t=6s

WHO. (2020, MARCH 16 Monday). Word Health Organization. Retrieved from Coronavirus disease (COVID-19) pandemic: Coronavirus disease (COVID-19) pandemic

WCAG. (2020, July 5 Sunday). Web Content Accessibility Guidelines. Retrieved from (WCAG) 2.0: https://www.w3.org/TR/2008/REC-WCAG20-20081211/

\section{Copyrights}

Copyright for this article is retained by the author(s), with first publication rights granted to the journal.

This is an open-access article distributed under the terms and conditions of the Creative Commons Attribution license (http://creativecommons.org/licenses/by/3.0/). 